\title{
Insulated Wall Systems to Tackle Global Warming
}

\author{
Swapan S. Saha \\ School of Computing, \\ Engineering and Mathematics, \\ University of Western Sydney, Australia \\ s.saha@uws.edu.au
}

\author{
Vivian W. Y. Tam \\ Corresponding author, School of Computing, \\ Engineering and Mathematics, \\ University of Western Sydney, Australia \\ vivianwytam@gmail.com.
}

DOI 10.5592/otmcj.2012.2.6

Research study

\section{Keywords}

Global warming, climate change, insulated wall system, residential, housing, Australia
BRIEF INTRODUCTION TO THE PROBLEM: THE GROWING AWARENESS OF CLIMATE CHANGE AND ITS LINK TO CARBON DIOXIDE EMISSIONS HAVE CAUSED CONCERNS IN THE COMMUNITY. A substantial amount of carbon dioxide emitted is due to the energy consumed by residential households. Heating/cooling of a residential house consumes a large proportion of the total household energy. Purpose: This paper explores the concept by comparing thermal efficiency of the four most common external wall structures, with varying amounts of insulation added in the context of Sydney, Australia.

Design/methodology/approach: Cost and thermal analysis for each wall type are calculated. Life cycle cost saving and payback period are then evaluated.

Findings: It is found that up to $95.7 \%$ cost saving can be achieved in heating/cooling in comparing the use of insulated wall systems and air film. Cement sheet wall system is found to be the most cost effective wall system for insulation with minimum $50 \%$ of cost saving can be achieved. The results also identify substantial energy cost required for heating/cooling a house without insulation when the climate gets extreme. The payback period for the installation of the insulated wall systems can be achieved in 4.98 years for normal climate condition or 2.58 years for extreme climate condition.

Practical implications: The community is currently at great risk of being unable to deal with climate change issue as not clear the effective use of insulated wall systems. This paper can help provide insight and suggestions for residential households in tackling global warming issue. 


\section{INTRODUCTION}

Climate change can be described as a long term change in climate patterns. Australian average temperature has been increased by $0.9^{\circ} \mathrm{C}$ since 1950 , with significant regional variations (Commonwealth Scientific and Industrial Research Organisation, 2007). The frequency of hot nights has been increased and the frequency of cold nights has been declined. This temperature change is supported by other sources with earth's surface temperature increasing $0.6^{\circ} \mathrm{C}$ over the last century (Comakll and Yuksel, 2004). The Australian Bureau of Meteorology predicted that temperature will rise between $0.4^{\circ}$ and $2^{\circ} \mathrm{C}$ by 2030 across Australia (Australian Bureau of Meteorology, 2010). It has also predicted that temperature will likely to rise between $1^{\circ}$ and $6^{\circ} \mathrm{C}$ by 2070 . It is expected to an increase in extreme events which is defined as temperatures over $35^{\circ} \mathrm{C}$, by $10-100 \%$ in 2030 and $20-600 \%$ in 2070. This increase in temperature predicted poses a severe problem for high variant climate cities, in increasing heating and cooling energy cost. Clearly wealthier households will be in a better position to protect themselves from the effects of global warming and extreme weather events than poorer households who will tend to invest in less effective measures or simply suffer the consequences.

The energy crisis experienced in 1973 has driven the importance in reducing household energy cost (Sisman, Kahya et al., 2007). Carbon trading has also recently been introduced in Australia, simply placing a tax on carbon dioxide emissions and hence further increasing energy cost. By using insulation, it is possible to reduce carbon dioxide emissions by $50 \%$ (Comakll and Yuksel, 2004). The introduction of wall and roof insulation into a building structure can achieve energy savings by up to $77 \%$ (Mohsen and Akash, 2001; Comakll and Yuksel, 2004). These savings equate to about $\$ 12.11$ per $\mathrm{m}^{2}$ over a period of 10 years (Comakll and Yuksel,
2004). Insulation is therfore economically feasble. Paying itself off many times over building life cycle through energy saving in heating/cooling reduction (Hasan, 1999; Sisman, Kahya et al., 2007). The optimum R-Value of insulation installs in a wall dependent on the climate and energy cost (Al-Sallal, 2003). The most effective way should be installed during the construction of a building as to retrofit it at a later time is considerably expensive (Lechner, 1991).

Optimum thickness of a single insulation layer found to be independent of its location in the wall, and that, when more than one insulation layer is used, their total optimum thickness is the same as the optimum thickness of a single layer (Al-Sanea and Zedan, 2011). Energy savings was significant by increasing the external wall insulation thickness in exterior zones facing all orientations under Beijing's climate, since the heating energy use was dominant and can be reduced remarkably with the increase in insulated thickness (Pan, Chan et al., 2012). Under Shanghai's climate, increasing external wall insulation thickness to over $26 \mathrm{~mm}$ would not reduce the sum of annual heating and cooling energy uses in the south-facing exterior zone, but would help save energy in exterior zones facing the other three orientations (Pan, Chan et al., 2012). For all exterior zones under Guangzhou's climate, it was, however, hardly possible to reduce the sum of annual heating and cooling energy uses by increasing the external wall insulation thickness (Pan, Chan et al., 2012). Under the experimental and simulation study on comparative energy and economic performance of walls used to enclose air-conditioned spaces under Thai climate, it was found that insulation can generally help improve thermal performance of walls, but the function that a space serves dictates where insulation should be placed and how cost effective it is (Chirarattananon, Hien et al., 2012).
It has also found that effect of wall orientation affects the required optimum insulation thickness in improving the environment (Ozel, 2011). $5 \cdot 5 \mathrm{~cm}$ for south oriented wall and $6 \mathrm{~cm}$ for north, east and west oriented walls found to be the optimum insulation thickness of extruded polystyrene (Ozel, 2011). The lowest value of the optimum insulation thickness and energy savings were obtained for the south oriented wall while payback period was almost same for all orientations. Optimum insulation thickness for different degree-day regions of Turkey had also studied with the determination with maximize annual energy savings for insulated external walls (Sisman, Kahya et al., 2007). Energy cost savings vary depending on the city and insulation materials (Ucar and Balo, 2010). Correlation between thermal conductivity and the thickness of selected insulation materials for building wall had been analyzed (Mahlia, Taufiq et al., 2007). It was found that a relationship between thermal conductivity and optimum thickness of insulation material is non-linear.

There are numerical papers in investigating optimum thickness for insulated materials; however, limited studies concerning different wall structures and their life cycle costing. This paper explores thermal efficiency of the four most common external wall structures, with varying amounts of insulation added in the context of Sydney, Australia. From this comparison, annual cost savings, life cycle analysis and payback period by using wall insulation can be evaluated. The most effective insulation system can thus be identified and explored.

\section{Research Methodologies}

The research is first focus on the types of external wall construction that currently present in Sydney's housing stock from the data collected by the Australian Bureau of Statistics (Australian Bureau of Statistics, 2008). The four most common wall types identified are used for cost and thermal analysis. 
After identifying four most common wall structures used in Sydney, Australia, relevant data is collected from Cordell Housing Building Cost Guide and Building Code of Australia for calculating the total cost of each wall system and their thermal properties. All data and results of the calculations are presented as "per m2".

The most cost effective external wall structure by calculating the amount of energy required to counteract external temperature variances forecast, is then explored. These results are then compared to the total cost of each wall system. Life cycle cost saving and payback period are then evaluated.

\section{Results and discussions}

According to the Australian Bureau of Statistics (Australian Bureau of Statistics, 2008), there are a total of $1,642,700$ houses in Sydney. The most common external wall is clay masonry veneer with about $42.21 \%$ followed by cavity clay masonry with about $34.41 \%$ (see Table 1). Weatherboard and cement sheet walling are shown as $6.93 \%$ and $7.77 \%$ respectively. The other wall types contribute a small minority; therefore, it will not be conducted any further investigation into their cost and thermal abilities in this paper.

\begin{tabular}{|c|c|c|}
\hline Wall types & Number of houses ('ooo) & Percentage \\
\hline Clay masonry veneer & 693.4 & $42.21 \%$ \\
\hline Cavity clay masonry & 565.2 & $34.41 \%$ \\
\hline Weatherboard & 113.8 & $6.93 \%$ \\
\hline Cement sheet & 127.6 & $7.77 \%$ \\
\hline Concrete / besser blocks & 57.2 & $3.48 \%$ \\
\hline Steel / aluminium & 28.9 & $1.76 \%$ \\
\hline Stone & 6.2 & $0.38 \%$ \\
\hline Other & 20.0 & $1.22 \%$ \\
\hline Did not know & 28.1 & $1.71 \%$ \\
\hline Total & $1,642.7$ & $100.00 \%$ \\
\hline
\end{tabular}

Table 1 External wall types in Sydney (Australian Bureau of Statistics, 2008)

Almost half of Sydney houses (about $48.63 \%$ ) have thermal insulation installed (see Table 2). Houses without

\begin{tabular}{|c|c|c|}
\hline Insulation & Number of houses ('ooo) & Percentage \\
\hline With insulation & 798.9 & $48.63 \%$ \\
\hline Without insulation & 467.1 & $28.43 \%$ \\
\hline Did not know & 376.8 & $22.94 \% Z$ \\
\hline Total & $1,642.7$ & $100.00 \%$ \\
\hline
\end{tabular}

Table 2 Houses with/without insulation in Sydney

(Australian Bureau of Statistics, 2008)

\begin{tabular}{|c|c|c|}
\hline Location & Number of houses ('ooo) & Proportion insulated (\%) \\
\hline Roof / ceiling & 679.7 & $85.08 \%$ \\
\hline Walls & 210.0 & $26.29 \%$ \\
\hline Floor & 11.0 & $1.38 \%$ \\
\hline
\end{tabular}

Table 3 Location of insulation installed in insulated Sydney houses

(Australian Bureau of Statistics, 2008) insulation is about $28.43 \%$ with the remaining $22.94 \%$ of houses are unsure. From the report of the Australian Bureau of Statistics (Australian Bureau of Statistics, 2008), the main reasons of not installing insulation are due to cost or because they are not the home owners. Another possible reason of not installing insulation is the use of reverse cycle air-conditioning for controlling the climate inside their houses. The large amount of households that do not know whether they have insulation installed or not, can be explained from the possibility of renting. (see Table 3). The presence of floor insulation represents only $1.38 \%$. With about $48.63 \%$ of Sydney houses installed insulation but only $26.29 \%$ of them installed on their walls, in which it is only about $13 \%$ of Sydney houses has wall insulation.

The cheapest wall to build is cement sheet wall which costs about \$130.17 per $\mathrm{m}^{2}$ (see Table 4 ). There is an approximately $44 \%$ cost saving when compared to building a cavity clay masonry wall which costs about $\$ 232.6$ per $\mathrm{m}^{2}$. Weatherboard wall and clay masonry veneer wall have a very similar price in which weatherboard costs $\$ 2.48$ per $\mathrm{m}^{2}$ more than clay masonry veneer. It should be noted that life cycle cost of a weatherboard wall and a cement sheet wall will be higher as the external surfaces require periodically re-painting.

\section{\begin{tabular}{l|l} 
Wall types & Cost (in AUDS $/ \mathrm{m}^{2}$ )
\end{tabular}}

\begin{tabular}{|c|c|}
\hline Clay masonry veneer & 198.90 \\
\hline Cavity clay masonry & 232.60 \\
\hline Weatherboard & 201.38 \\
\hline Cement sheet & 130.17 \\
\hline
\end{tabular}

Table 4 Cost of wall

(Reed Construction Data, 2008)

There are different types of insulation methods, including blanket, concrete block, foam board, insulating concrete 
forms, loose-fill and blown-in, reflective system, rigid fibrous or fibre, sprayed form and foamed-in-place, and structural insulated panel (US Department of Energy, 2012). Blanket insulation is the most common and widely available type of insulation, which comes in the form of batts or rolls. Batts and rolls are available in widths suited to standard spacing of wall studs, attic trusses or rafters and floor joists. Therefore, this paper compares different insulation materials for Blanket insulation; fiberglass and rockwool are the two most common materials for thermal insulations in this method and thus are used in this paper for further analysis. Table 5 clearly identifies that fiberglass insulation is cheaper than rockwool for supply and install. It is also shown that rockwool insulation is exponentially more costly as its R-Value increases. The cost of fiberglass insulation rises almost linearly as its R-Value increases. R-Value is a measure of thermal resistance of a material or wall element, which is measured in $\mathrm{m}^{2} \mathrm{~K} / \mathrm{W}$ where $\mathrm{K}$ is the degree of Kelvin or Celsius, and W is the amount of heat flow in watts. The R-Value is the common measure used to compare different insulation materials in the construction industry.

Based on Table 4 and Table 5, Table 6 and Table 7 show the cost of the four external wall types with varying R-Val-

\begin{tabular}{|c|c|c|c|c|c|}
\hline \multirow{2}{*}{ Wall types } & \multicolumn{5}{|c|}{ Cost (in AUD \$/m $\mathbf{m}^{2}$} \\
\cline { 2 - 7 } & $\mathbf{R 0}$ & $\mathbf{R} 1.5$ & $\mathbf{R 2}$ & $\mathbf{R} 2.5$ & $\mathbf{R} 3$ \\
\hline Clay masonry veneer & 198.90 & 213.00 & 213.46 & 216.36 & 223.04 \\
\hline Cavity clay masonry & 232.60 & 246.70 & 247.16 & 250.06 & 256.74 \\
\hline Weatherboard & 201.38 & 215.48 & 215.94 & 218.84 & 225.52 \\
\hline Cement sheet & 130.17 & 144.27 & 144.73 & 147.63 & 154.31 \\
\hline
\end{tabular}

Table 7 Cost of wall with rockwool insulation (Reed Construction Data, 2008)

\begin{tabular}{|c|c|c|c|c|c|}
\hline Wall types & Ro & $\mathbf{R} \mathbf{1 . 5}$ & $\mathbf{R} 2$ & $\mathbf{R} 2.5$ & $\mathbf{R} 3$ \\
\hline Clay masonry veneer & 0.55 & 2.05 & 2.55 & 3.05 & 3.55 \\
\hline Cavity clay masonry & 0.68 & 2.18 & 2.68 & 3.18 & 3.68 \\
\hline Weatherboard & 0.47 & 1.97 & 2.47 & 2.97 & 3.47 \\
\hline Cement sheet & 0.41 & 1.91 & 2.41 & 2.91 & 3.41 \\
\hline
\end{tabular}

\section{Table 8 R-Values of walls with insulation} (Australian Building Codes Board, 2008)

ues of fiberglass and rockwool insulation installed respectively. The insulation level with Ro indicates a wall with no insulation. The cement sheet wall system is found to be the cheapest with the cavity clay masonry being the most expensive wall system.

Based on the information from the Australian Building Codes Board (Australian Building Codes Board, 2008), Table 8 shows the calculated R-Values for different types of wall systems. It should be noted that the R-Values linearly rise for all four wall types when larger amounts of insulation are added. Therefore, the resistance to heat trans-

\begin{tabular}{|c|c|c|c|c|}
\hline \multirow{2}{*}{ Insulation types } & \multicolumn{4}{|c|}{ Cost (in AUD \$/m²) } \\
\cline { 2 - 5 } & $\mathbf{R} 1.5$ & $\mathbf{R 2}$ & $\mathbf{R} 2.5$ & $\mathbf{R} 3$ \\
\hline Fibreglass & 9.85 & 11.97 & 13.13 & 13.79 \\
\hline Rockwool & 14.10 & 14.56 & 17.46 & 24.14 \\
\hline
\end{tabular}

Table 5 Cost of insulation for supply and install (Reed Construction Data, 2008)

\begin{tabular}{|c|c|c|c|c|c|}
\hline \multirow{2}{*}{ Wall types } & \multicolumn{5}{|c|}{ Cost (in AUD \$/m²) } \\
\cline { 2 - 7 } & Ro & $\mathbf{R} 1.5$ & R2 & R2.5 & R3 \\
\hline Clay masonry veneer & 198.90 & 208.75 & 210.87 & 212.03 & 212.69 \\
\hline Cavity clay masonry & 232.60 & 242.45 & 244.57 & 245.73 & 246.39 \\
\hline Weatherboard & 201.38 & 211.23 & 213.35 & 214.51 & 215.17 \\
\hline Cement sheet & 130.17 & 140.02 & 142.14 & 143.30 & 143.96 \\
\hline
\end{tabular}

Table 6 Cost of wall with fibreglass insulation (Reed Construction Data, 2008) fer is proportional to the amount of thermal insulation used. For the cavity clay masonry wall and the cement sheet wall without insulation, they have the highest R-Value of about $0.68 \mathrm{~m}^{2} \mathrm{~K} / \mathrm{W}$ and the lowest R-Value of about $0.41 \mathrm{~m}^{2} \mathrm{~K} / \mathrm{W}$ respectively in which it provides the most resistant and the worse resistant respectively for heat transfer.

Based on the required annual heating and cooling for normal climate condition of about 6-hour heating / cooling required per day (see Table 9), cost for annual heating and cooling can be found by estimating energy charges of about \$0.127 per Kwh/m² (see Table 10). It should be noted that all wall systems provide different levels of saving in comparing to air film (see Table 11). Air film is a plastic film which can be applied for glass windows in reducing heat transfer, in which the film is attached to the window frame using double sided pressure sensitive tape to create a double glazed system with a still air layer about 0.5 inches thick between the film and the glass windows. In comparing the cost of air film, the largest cost saving is an $\mathrm{R}_{3}$ insulated cavity clay masonry wall with a saving of about $\$ 27.34$ per $\mathrm{m}^{2}$ per year, in which it is about $95.7 \%$ cost saving. But the three other wall systems that are $R_{3}$ insulated produced very similar 
results with the worst performer being cement sheet with only a \$0.10 per $\mathrm{m}^{2}$ per year difference in saving.

It is also shown that the largest saving is achieved from an un-insulated wall system to an insulated system. The largest margin is found between the insulated and un-insulated cement sheet wall system, which is the most cost effective wall system for insulation. The insulated cement sheet wall system can achieve minimum $50 \%$ cost saving. The least cost effective wall system is insulated cavity clay masonry, however, it still has at least $30 \%$ cost saving. Clay masonry veneer and weatherboard wall systems are very similar in terms of their cost effectiveness.

In considering the life cycle cost for the use of insulated wall system and life cycle cost saving for the system in comparing the use of air film, an example of the calculation for a Ro insulated clay masonry veneer wall system is shown in Table 12. The cost of the wall system and the annual cost saving can be found from Table 4 and Table 11 respectively. By considering an inflation rate of about $3 \%$ per year, the life cycle cost saving can be found by accumulating the annual cost saving. The payback period can then be found by comparing between the cost of the wall system and the life cycle cost saving.

It is found that the most cost effective wall system should take the least amount of time to payback. The cement sheet walls with $R_{3}$ and $R_{2}$ insulation are the most cost effective wall systems with fiberglass and rockwool insulation respectively in which the payback period are about 4.98 and 5.10 years respectively (see Table 13). The clay masonry veneer and weatherboard wall systems are very similar both taking about 7.5 years to payback when insulation has been added. The least cost effective wall system with insulation is the cavity clay masonry which takes at least 8 years to payback. It should also be noted that it can reduce the payback period by about 1.5 years when the

\begin{tabular}{|c|c|c|c|c|c|}
\hline Wall types & Ro & $\mathbf{R} 1.5$ & $\mathbf{R}$ & $\mathbf{R} 2.5$ & $\mathbf{R} 3$ \\
\hline Normal climate condition & & & & \\
\hline Clay masonry veneer & 65.45 & 17.56 & 14.12 & 11.80 & 10.14 \\
\hline Cavity clay masonry & 52.94 & 16.51 & 13.43 & 11.32 & 9.78 \\
\hline Weatherboard & 76.60 & 18.27 & 14.57 & 12.12 & 10.37 \\
\hline Cement sheet & 87.80 & 18.85 & 14.94 & 12.37 & 10.56 \\
\hline Air film & 225.00 & & & & \\
\hline Extreme climate condition & & & & & \\
\hline Clay masonry veneer & 130.91 & 35.12 & 28.24 & 23.61 & 20.28 \\
\hline Cavity clay masonry & 105.88 & 33.03 & 26.87 & 22.64 & 19.57 \\
\hline Weatherboard & 153.19 & 36.55 & 29.15 & 24.24 & 20.75 \\
\hline Cement sheet & 175.61 & 37.70 & 29.88 & 24.74 & 21.11 \\
\hline Air film & 450.00 & & & & \\
\hline
\end{tabular}

Table 9 Required annual heating/cooling for the normal and extreme climate condition (in Kwh/m²) (Reed Construction Data, 2008)

\begin{tabular}{|c|c|c|c|c|c|}
\hline Wall types & Ro & $\mathbf{R} 1.5$ & $\mathbf{R} 2$ & $\mathbf{R} 2.5$ & $\mathbf{R} 3$ \\
\hline Normal climate condition & & & & \\
\hline Clay masonry veneer & 8.31 & 2.23 & 1.79 & 1.50 & 1.29 \\
\hline Cavity clay masonry & 6.72 & 2.10 & 1.71 & 1.44 & 1.24 \\
\hline Weatherboard & 9.73 & 2.32 & 1.85 & 1.54 & 1.32 \\
\hline Cement sheet & 11.15 & 2.39 & 1.90 & 1.57 & 1.34 \\
\hline Air film & 28.58 & & & & \\
\hline Extreme climate condition & & & & & 2.58 \\
\hline Clay masonry veneer & 16.63 & 4.46 & 3.59 & 3.00 & 2.48 \\
\hline Cavity clay masonry & 13.45 & 4.19 & 3.41 & 2.88 & 2.64 \\
\hline Weatherboard & 19.46 & 4.64 & 3.70 & 3.08 & 2.68 \\
\hline Cement sheet & 22.30 & 4.79 & 3.79 & 3.14 & \\
\hline Air film & 57.15 & & & \\
\hline
\end{tabular}

Table 10 Annual cost of heating/cooling for the normal and extreme climate condition (in AUD\$ $/ \mathrm{m}^{2}$ )

\begin{tabular}{|c|c|c|c|c|c|}
\hline Wall types & Ro & $\mathbf{R} 1.5$ & $\mathbf{R}_{\mathbf{2}}$ & $\mathbf{R}_{\mathbf{2} .5}$ & $\mathbf{R}_{\mathbf{3}}$ \\
\hline \multicolumn{6}{|c|}{ Normal climate condition } \\
\hline Clay masonry veneer & 20.27 & 26.35 & 26.79 & 27.08 & 27.29 \\
\hline Cavity clay masonry & 21.86 & 26.48 & 26.87 & 27.14 & 27.34 \\
\hline Weatherboard & 18.85 & 26.26 & 26.73 & 27.04 & 27.26 \\
\hline Cement sheet & 17.43 & 26.19 & 26.68 & 27.01 & 27.24 \\
\hline \multicolumn{6}{|c|}{ Extreme climate condition } \\
\hline Clay masonry veneer & 40.52 & 52.69 & $53 \cdot 56$ & 54.15 & $54 \cdot 57$ \\
\hline Cavity clay masonry & 43.70 & 52.96 & 53.74 & 54.27 & 54.67 \\
\hline Weatherboard & 37.69 & 52.51 & 53.45 & 54.07 & $54 \cdot 51$ \\
\hline Cement sheet & 34.85 & 52.36 & 53.36 & 54.01 & 54.47 \\
\hline
\end{tabular}

Table 11 Annual cost savings compared to air film for the normal and extreme climate condition (in AUD\$ $/ \mathrm{m}^{2}$ ) 


\begin{tabular}{|c|c|c|c|}
\hline Year & Cost of the wall system & Annual cost saving & Life cycle cost saving \\
\hline 1 & 198.90 & 20.27 & 20.27 \\
\hline 2 & - & 20.88 & 41.15 \\
\hline 3 & - & 21.50 & 62.65 \\
\hline 4 & - & 22.15 & 84.80 \\
\hline 5 & - & 22.81 & 107.62 \\
\hline 6 & - & 23.50 & 131.11 \\
\hline 7 & - & 24.20 & 155.32 \\
\hline 8 & - & 24.93 & 180.25 \\
\hline 9 & - & 25.68 & 205.93 \\
\hline
\end{tabular}

Table 12 Life cycle cost of using a Ro insulated clay masonry veneer wall system (AUD\$)

\begin{tabular}{|c|c|c|c|c|c|}
\hline Wall types & Ro & R1.5 & $\mathbf{R}_{2}$ & R2.5 & $\mathbf{R}_{\mathbf{3}}$ \\
\hline \multicolumn{6}{|c|}{ Normal climate condition with fiberglass insulation } \\
\hline Clay masonry veneer & 8.73 & 7.21 & 7.17 & 7.14 & 7.11 \\
\hline Cavity clay masonry & $9 \cdot 37$ & 8.21 & 8.17 & 8.13 & 8.09 \\
\hline Weatherboard & 9.40 & 7.31 & 7.26 & 7.78 & 7.19 \\
\hline Cement sheet & 6.84 & 5.03 & 5.02 & 5.00 & 4.98 \\
\hline \multicolumn{6}{|c|}{ Normal climate condition with rockwool insulation } \\
\hline Clay masonry veneer & 8.73 & 7.34 & 7.25 & 7.27 & 7.42 \\
\hline Cavity clay masonry & $9 \cdot 37$ & 8.33 & 8.24 & 8.25 & 8.39 \\
\hline Weatherboard & 9.40 & 7.44 & 7.66 & 7.35 & 7.50 \\
\hline Cement sheet & 6.84 & 5.17 & 5.10 & 5.14 & $5 \cdot 31$ \\
\hline \multicolumn{6}{|c|}{ Extreme climate condition with fiberglass insulation } \\
\hline Clay masonry veneer & 4.64 & 3.80 & 3.77 & 3.75 & 3.74 \\
\hline Cavity clay masonry & 5.01 & $4 \cdot 35$ & $4 \cdot 33$ & $4 \cdot 31$ & 4.29 \\
\hline Weatherboard & 5.03 & 3.85 & 3.82 & 3.80 & 3.78 \\
\hline Cement sheet & 3.59 & 2.61 & 2.61 & 2.59 & 2.58 \\
\hline \multicolumn{6}{|c|}{ Extreme climate condition with rockwool insulation } \\
\hline Clay masonry veneer & 4.64 & 3.87 & 3.82 & 3.83 & 3.91 \\
\hline Cavity clay masonry & 5.01 & 4.42 & $4 \cdot 37$ & 4.38 & 4.46 \\
\hline Weatherboard & 5.03 & 3.93 & 3.87 & 3.88 & 3.96 \\
\hline Cement sheet & 3.59 & 2.68 & 2.64 & 2.66 & 2.76 \\
\hline
\end{tabular}

Table 13 Payback years for the different climate condition with different insulations

insulation is added, which shows that installing insulation can help achieve cost effectiveness for the wall systems more effectively and efficiently. In this study, it is assumed that maintenance is not required before the payment period achieved; therefore, no maintenance cost is considered in the calculation.

To simulate a warming climate condition, the required annual heating/ cooling is increased double from about 6-hour (normal climate condition) to 12hour (extreme climate condition) heating/cooling required per day. It is shown that the required annual heating/cooling and the cost of annual heating/cooling are double about the normal climate condition to extreme climate condition. This brings the highest annual cost saving for $\mathrm{R}_{3}$ insulated cavity clay masonry wall system with about $\$ 54.67$ per $\mathrm{m}^{2}$ per year.

In comparing the annual cost of heating/cooling for the example of cement sheet wall system with the normal and extreme climate condition (see Figure 1), it should be noted that the annual cost for heating/cooling for the extreme climate condition is significantly reduced when the insulation is installed. This shows that it is necessary to install wall insulation for achieving cost effectiveness with the urge from climate change and global warming.

By simulating the climate change condition in the calculation, the payback period is reduced as the annual cost saving is increased with the high annual usage of energy. It is about 2.5 years saving in payback period in doubling the energy required between normal climate condition and extreme climate condition. It is shown that insulated wall systems become more economically viable in the climate change environment.

\section{Conclusion}

This paper examined and compared thermal efficiency of the four most common external wall structures with varing amounts of insulation added. It was found that about $87 \%$ houses in Sydney do not have insulation in their external walls. The most cost effective wall type in dealing with external temperature variances was found to be insulated fiberglass cement wall sheeting with RValue of 3 of about $95.7 \%$ cost saving can be achieved in heating/cooling in comparing the use of air film. Cement sheet wall system was found to be the most cost effective wall system for in- 


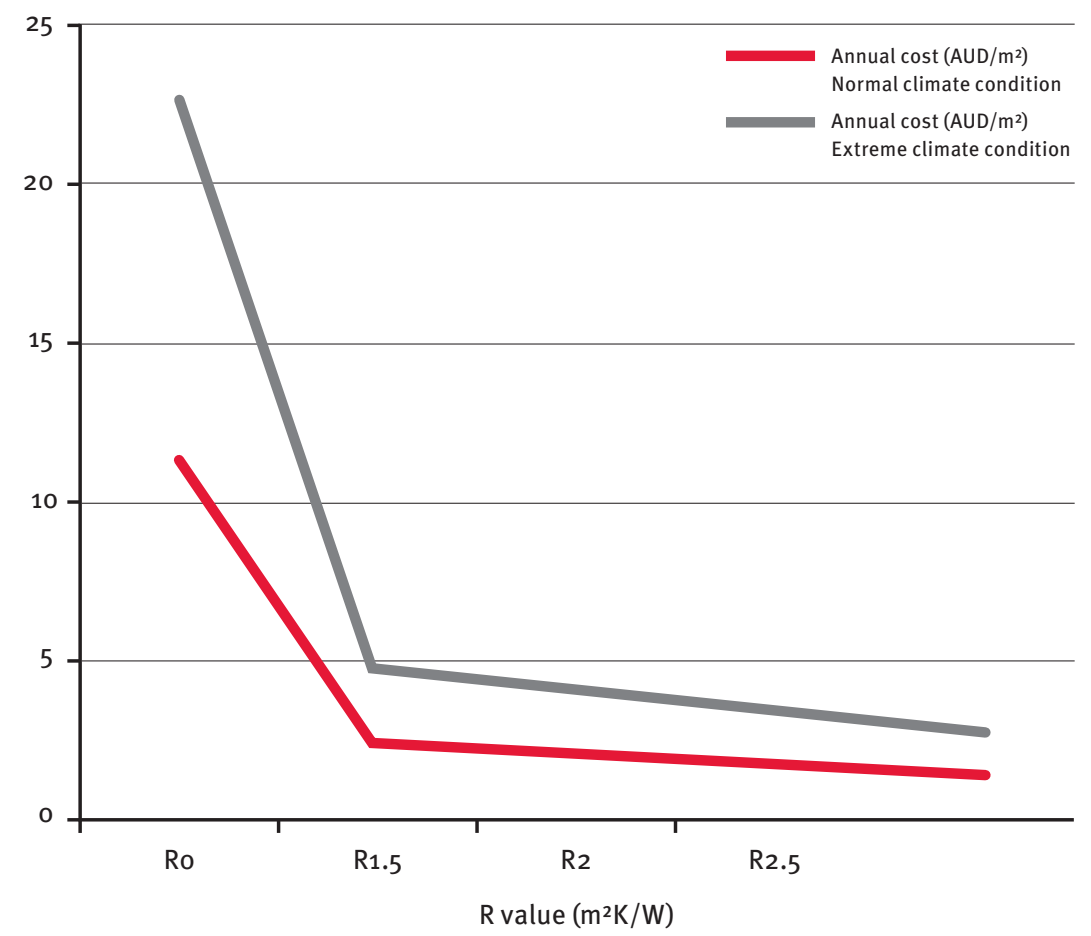

Figure 1: Annual cost of heating/cooling for the cement sheet wall systems

sulation with minimum $50 \%$ of cost saving can be achieved. Simulating climate change with increasing the numbers of hot days highlighted the need to insulate external walls. The results of this paper also identified substantial energy cost requires to heat/cool a house without insulation as the climate gets hotter to stay comfortable. The payback period for the installation of the system can be achieved in 4.98 years for normal climate condition or $\mathbf{2 . 5 8}$ years for extreme climate condition. This paper can greatly affect residential households to effectively and efficiently tackle climate change and global warming issues.

\section{Acknowledgments}

The authors would like to thank Mr. Peter Thanos for the collection of data for this study.

\section{References}

Al-Sallal, K. A. (2003). 'Comparison between polystyrene and fiberglass roof insulation in warm and cold climates' Renewable Energy Vol. 28, No.4, pp. 603-611.

Al-Sanea, S. A. and Zedan, M. F. (2011). 'Improving thermal performance of building walls by optimizing insultation layer distribution and thickness for same thermal mass' Applied Energy Vol. 88, No. 9, pp. 3113-3124.

Australian Building Codes Board (2008). Building code of Australia Volume Two, Canberra: Australian Government and States and Territories of Australia.

Australian Bureau of Meteorology (2010). "Australian climate change." Retrieved 16 September, 2010, from www.bom.gov.au

Australian Bureau of Statistics (2008). Environmental issues: energy use and conservation, Australian Bureau of Statistics, Commonwealth of Australia.

Chirarattananon, S., Hien, V. D. and Tummu, P. (2012). 'Thermal performance and cost effectiveness of wall insulation under Thai climate' Energy and Buildings Vol. 45, No. 1, pp. 82-90.

Comakll, K. and Yuksel, B. (2004). 'Environmental impact of thermal insultation thickness in buildings' Applied Thermal Engineering Vol. 24, No. 5-6, pp. 933-940.
Commonwealth Scientific and Industrial Research Organisation (2007). Climate change in Australia, Commonwealth Scientific and Industrial Research Organisation, Australia.

Hasan, A. (1999). 'Optimizing insulation thickness for buildings using life cycle cost' Applied Energy Vol. 63, No. 2, pp. 115-124.

Lechner, N. (1991). Heating, cooling, lighting: design methods for architects, New York: Wiley.

Mahlia, T. M. I., Taufiq, B. N. and Masjuki, H. H. (2007). 'Correlation between thermal conductivity and the thickness of selected insulation materials for building wall' Energy and Buildings Vol. 39, No. 2, pp. 182-187.

Mohsen, M. S. and Akash, B. A. (2001). 'Some prospect of energy savings in buildings' Energy Conservation and Management Vol. 42, No. 11, pp. 1307-1315.

Ozel, M. (2011). 'Effect of wall orientation on the optimum insulation thickness by using a dynamic method' Applied Energy Vol. 88, No. 7, pp. 2429-2435.

Pan, D., Chan, M., Deng, S. and Lin, Z. (2012). 'The effects of external wall insulation thickness on annual cooling and heating energy uses under different climates' Applied Energy Vol. In Pres, No.

Reed Construction Data (2008). Cordell housing building cost guide, Sydney, Cordell.

Sisman, M., Kahya, E., Aras, N. and Aras, H. (2007). 'Determination of optimum insulation thickness of the external walls and roof (ceiling) for Turkey's different degree-day regions' Energy Policy Vol. 35, No. 10, pp. 5151-5155.

Sisman, N., Kahya, E., Aras, N. and Aras, H. (2007). 'Determination of optimum insulation thicknesses of the external walls and roof (ceiling) for Turkey's different degree-day regions' Energy Policy Vol. 35, No. 10, pp. 5151-5155.

Ucar, A. and Balo, F. (2010). 'Determination of the energy savings and the optimum insulation thickness in the four different insulated exterior walls' Renewable Energy Vol. 35, No. 1, pp. 88-94.

US Department of Energy (2012). "Types of insulation.” Retrieved 12 November 2012, 2012, from http://energy.gov/energysaver/ articles/types-insulation. 